\title{
IMPERFECTIONS OF SUPERVISORY PRUDENTIAL REGULATIONS RELATED TO CREDIT EXPOSURES SECURED BY MORTGAGES
}

\section{Edward Wiszniowski}

Wrocław University of Economics, Wrocław, Poland

e-mail: edward.wiszniowski@ue.wroc.pl

(C) 2018 Edward Wiszniowski

This is an open access article distributed under the Creative Commons Attribution-NonCommercial-NoDerivs license (http://creativecommons.org/licenses/by-nc-nd/3.0/)

DOI: 10.15611/fins.2018.1.06

JEL Classification: G210, G280

\begin{abstract}
The credibility of economic information provided by banks is one of the key elements of building trust between the institutions and the economic environment. The activities of the national banking sector, due to the special responsibility for the entrusted deposits, is subject to restrictive legal regulations and is controlled by the banking supervision. The legal act binding the banks and regulating, among others, the rules of credit risk measurement derived from mortgage-secured loans is the S Recommendation which was issued by the Financial Supervision Commission. The publication discusses the imperfections of this supervisory regulation with regard the defined concepts and recommended methods for the measurement of credit exposure, the interpretation and the method of determining the value of mortgage security and $L t V$.
\end{abstract}

Keywords: $L t V$, mortgage security, real estate, credit risk, S Recommendation.

\section{Introduction}

A mortgage is a limited property right for the provision of designated receivables, under which the creditor may claim satisfaction of their claims with the property regardless of the current ownership of the property, and with priority over personal creditors of the owner [Kostecki 2014]. For banks, this form of security is considered as one of the most popular and most commonly used. According to the Financial Supervision Commission (Komisja Nadzoru Finansowego) on 31.03.2016 the domestic banking sector had total assets equal to 1,631 billion PLN, of which the status of loans granted to the non-financial sector amounted to 967 million PLN (59.3\%), and loans mortgage-backed amounted to 565 million PLN, which accounted for $58.4 \%$ of the banks' loan portfolio. It is worth noting that loans secured by mortgages are characterized by high quality, if the concept of this quality is to be understood as the ratio of the loan portfolio of impaired value to the total value of 
the portfolio. While for 31.03.2016 the quality of the loan portfolio in relation to the non-financial sector stood at $7.4 \%$, in the case of housing loans the ratio was $1.1 \%$ (10.9 million PLN), while the remaining loans secured by mortgage amounted to $0.1 \%$ ( 0.9 billion PLN).

The causes of the popularity of the mortgage as good collateral for the loans should be seen in the legal certainty of real estate resulting from its specific records held by the departments of land registers in courts of law, a relatively low volatility in value over time compared with other security measures, as well as the positive impact on the capital adequacy ratio of the bank, which is associated with the possibility of lowering the basics of creating specific provisions for risk related to banking activity [Rozporządzenie Parlamentu Europejskiego 2013].

Securing a mortgage established in favour of the creditor on the property, however, has significant drawbacks, which include mainly high, compared to other loans, amounts of the banks' exposure to individual exposures as well as the possibility of increasing systemic risk, understood as independent from banks negative impact of the environment on the value of the securities [Uchwała nr 148/2013]. Rapid or uncontrolled rise in the credit shares in connection with a uniform portfolio of securities and untimely settlement of commitments by borrowers or cessation of repayment, in the conditions of recovery led by banks, may be the source of the oversupply of properties on the market, which will result in a decline in their prices. The negative effects of this phenomenon can be multiplied in case of occurrence in the banks' assets or their associated companies of complex financial instruments based e.g. on indices of growth in real estate prices. These processes, combined with the decline of confidence in the economic information are considered to be one of the main causes of the global financial crisis of 2008 [Roubini, Mihm 2011]. This state justifies the importance of the discussed subject and encourages discussion about the principles of risk measurement and the purposefulness of modifying some of the concepts related to credit exposures secured by mortgages.

Banking activities in Poland, like no other activity based on freedom of economic activity [Ustawa z 2 lipca 2004], is closely regulated and monitored by the State authorities which include, among others, the Financial Supervision Commission. This authority, within its statutory powers, focuses its attention on the objective of security for the money deposited in the banking sector, and one way of achieving this requirement is the legislative activity whose hierarchical level corresponds to the implementation rules issued by the ministers of the various departments. Under this mandate, the Financial Supervision Authority issues recommendations that can be defined as instructions or collections of good practices relating to different categories of banking risk and the relationship of banks with the economic environment. One of the most important recommendations of the Financial Supervision Commission is the S Recommendation on good practices in the mortgage secured credit exposures. This act, though modified four times since the release of its first version, still contains numerous imperfections associated with the imprecise definition of certain terms, in 
particular credit exposure and $L t V$ which is the basic measure of the level of this category of risk. The signalled problem, which is the subject of this study, should be regarded as important because banks are required to disclose their achievements not only in the financial statements, but also in other reports, including those related to incurring the risk derived from credit exposures secured by mortgages. Incorrectly or imprecisely defined indicators limit or make it impossible to ensure the presentation of the actual level of risk incurred by the bank and thus do not lead to the presentation of an accurate picture of their economic development. The intention of the author was also to link the practical problems with science, which in terms of content can be defined as "specialised practice" [Apanowicz 2000].

\section{Credit exposures and their value}

Credit exposure is defined as the bank's amount due to loans, credits, debt limit (including for credit and debit cards), the acquired receivables, checks and bills of exchange, realised guarantees, other receivables of a similar nature, and off-balance commitment sheet [Uchwała nr 148/2013). The term "exposure" means an asset or an off-balance sheet item [Rozporządzenie Parlamentu Europejskiego 2013].

According to the $\mathrm{S}$ Recommendation, credit exposure secured by mortgages $(\mathrm{EKZH})$ is always the one which pertains to the financing of real estate and for which collateral has been established in the form of a mortgage or collateral that is the destined security. In other cases, the mortgage-secured credit exposure is considered to be those exposures with original maturities of longer than three years, and where the mortgage is or will be the dominant collateral, understood as mortgage constituting the only collateral for the exposure or whose share represents more than $50 \%$ of the original value of this exposure.

It should be noted that there is a quite unique way of understanding the mortgages by the FSC as a dominant collateral. The amount of the entry of the mortgage does pertain to the portfolio of the collateral, but to the original amount of the exposition.

In case of the example presented in Table 1, assuming that the loan was granted for a purpose other than related to real estate financing, and the term of its maturity is longer than three years, credit exposure should be considered secured by mortgage despite the fact that the share of the mortgage in the security portfolio is lower than $50 \%$.

The S Recommendation makes no reference to the method of measuring the EKZH value. It seems, however, that since the term "exposure" refers to the position of assets and off-balance sheet liabilities, and the definition of EKZH evokes the term "receivables", the proper way of determining that the position should be sought in the legal regulations of accounting. According to the art. 28 paragraph 1 point $7 \mathrm{a}$ of the Accounting Act, receivables and loans classified as financial assets may be valued at amortized cost [Ustawa z 29 września 1994]. Optional valuation of receivables from the titles of credit and loans, however, pertains to non-bank 


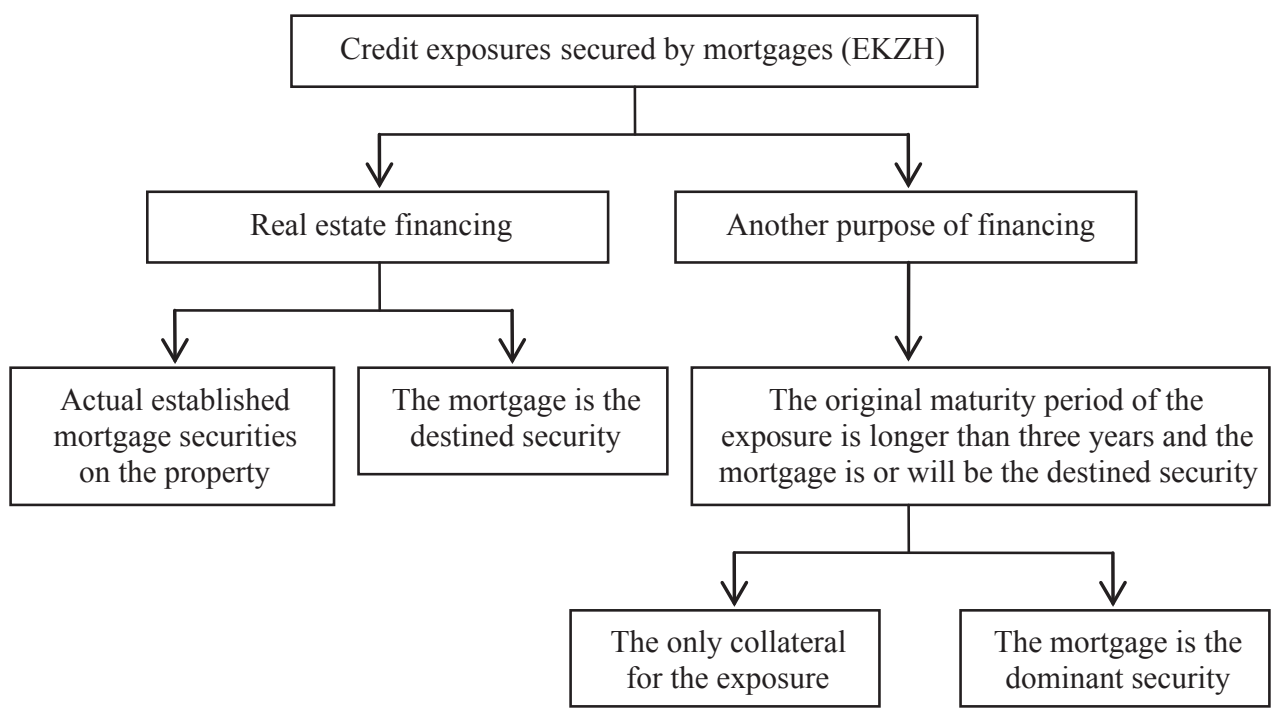

Figure 1. Criteria for the recognition of credit exposures secured by mortgages

Source: own study based on the S Recommendation.

Table 1. A method for the recognition of collateral dominant in Recommendation S

\begin{tabular}{|l|c|}
\hline \multicolumn{1}{|c|}{ Specification } & \multicolumn{1}{|c|}{ Value } \\
\hline 1. The original amount of credit exposure & $1,000,000$ PLN \\
\hline 2. The value of the property & $2,000,000$ PLN \\
\hline $\begin{array}{l}\text { 3. The amount of the entry in the section IV of the register of real estate } \\
\text { (mortgage) }\end{array}$ & 600,000 PLN \\
\hline 4. The value other than the mortgage, the collateral & $1,500,000$ PLN \\
\hline A. The ratio of the mortgage to the original amount of the EKZH & $60.0 \%$ \\
\hline B. The share of the mortgage in the security portfolio & $28.6 \%$ \\
\hline
\end{tabular}

Source: own elaboration.

business entities. In the case of banks, depending on the adopted rules, there are the International Accounting Standards and International Financial Reporting Standards [Rozporządzenie Komisji (WE) nr 1126/2008] or the implementing the Accounting Act rules [Rozporządzenie Ministra Finansów 2010]. However, regardless of the accepted sources, the laws shaping the accounting policy of banks, the loans and other receivables of the bank that are not held for trading (they are held to maturity) are measured at an amortized cost using the effective interest rate.

The term amortized cost of financial assets or financial liabilities should be understood as the amount at which the asset was first introduced into the accounts, net of repayment of debt, properly adjusted for the cumulative amount of the discounted 
difference between the initial component and its value at maturity, calculated using the effective interest rate (ESP), as well as net of write-downs in respect to specific provisions. ESP is the interest rate that discounts the expected stream of future payments to the current net amount during the period to maturity of the credit or the loan, taking into the account the estimates of the cash flows arising under the contract, including fees and commissions, but without taking into account potential future losses related to the uncollectibility of these financial assets [Rozporządzenie Ministra Finansów 2010].

The formula for the calculation of the balance sheet at amortized cost is therefore as follows:

$$
W_{k}^{\text {bil(ESP) }}=\left(W_{k-1}^{\text {bil(ESP) }}-C F_{k}\right) \times\left(1+\operatorname{ESP}^{\frac{t_{k}-t_{k-1}}{365}}\right)-R C_{k},
$$

where: $W_{k}^{\text {bil(ESP) }}$ and $W_{k-1}^{\text {bil(ESP) }}$ - respectively: the balance of the loan during $k$ and $k-1$ preceding the current valuation, calculated at amortized cost, taking into account the ESP; $C F_{k}-$ cash flow during $k ; t_{k}-t_{k-1}-$ the number of days that have elapsed since the last valuation date till the balance sheet date; $365-$ fixed number reflecting the number of days in the year; $R C_{k}$ - write-off of impairment losses of the exposure (specific provision).

The effective interest rate can be determined by solving the following equation:

$$
P V=\sum_{k=1}^{n} \frac{C F_{k}}{(1+\mathrm{ESP})^{\frac{t_{k}-t_{k-1}}{365}}},
$$

where: $P V$ - present value of the exposure at the time of the valuation. At the time of the loan, $P V$ is equal to the difference between the amount of the loan and paid fees and charges.

The use of the model of balance sheet valuation, therefore, refers to:

- the present value, which corresponds to the sum of the discounted cash flows according to ESP,

- the net value, which results from the obligation to update values in connection with credit risk incurred by the bank,

- the projected cash flows.

According to the author, this approach is not appropriate, because the banks, as creditors, are more interested in the current outstanding amount of the loan together with interest (the amount of the required payment) than the balance value based on an algorithm of discounted future cash flows. 


\section{Example 1}

On 12.05.2016, the bank granted a loan to finance real estate (land and construction of a storage) under the following conditions:

- the amount of credit was 500,000 PLN, one-off (payment of) commissioning on 12.05.2016,

- the nominal interest rate of $6.90 \%$ per annum,

- commission of $7.5 \%$ of the loan amount deducted on the day of its launch,

- the date of maturity of the last instalment of the loan on 12.05.2020 (4-year term of the loan),

- the planned method of repayment: eight equal repayments every six months, the interest payable on repayment of principal instalments,

- collateral for the loan: mortgage in the amount of 500 thousand PLN on a property with a market value of 600 thousand PLN (constant value of the collateral).

In the period of the loan, the borrower, which was a capital company, has failed to pay the first three principal instalments and interest. In this situation, the bank was forced to reclassify the credit exposure to a risk group. Reclassification of the loan to the questionable group was done immediately due to the affected share capital of the debtor; and subsequently it was moved to a lost group [Rozporządzenie Ministra Finansów 2008].

Table 2. Planned and actual distribution of payments, as well as the balance value and the actual condition of the borrower's debt to the conditions described in Example 1

\begin{tabular}{|c|c|c|c|c|c|c|}
\hline \multirow[b]{2}{*}{ Date } & \multirow[b]{2}{*}{$\begin{array}{l}\text { Risk } \\
\text { group* }\end{array}$} & \multirow[b]{2}{*}{$\begin{array}{l}\text { Payments } \\
\text { forecast }\end{array}$} & \multicolumn{3}{|c|}{ Actual payments } & \multirow[b]{2}{*}{$\begin{array}{c}\text { Difference } \\
\text { col. } 6 \text { - col. } 5\end{array}$} \\
\hline & & & $\begin{array}{c}\text { Balance sheet } \\
\text { value }\end{array}$ & $\begin{array}{l}\text { The actual } \\
\text { amount } \\
\text { of the } \\
\text { payment }\end{array}$ & $\begin{array}{c}\text { Receivables } \\
\text { of the bank in } \\
\text { the amount } \\
\text { of the } \\
\text { required } \\
\text { payment }\end{array}$ & \\
\hline 12.05 .2016 & $\mathrm{~N}$ & $-462,500.00$ & $462,619.01$ & $-462,500.00$ & $500,094.52$ & $37,475.51$ \\
\hline 12.11 .2016 & $\mathrm{~N}$ & $79,891.78$ & $485,047.12$ & 0.00 & $517,486.30$ & $32,475.51$ \\
\hline 13.11.2016 & Q & 0.00 & $363,878.95$ & 0.00 & $517,580.82$ & $153,701.87$ \\
\hline 12.05 .2017 & Q & $77,469.69$ & $381,127.62$ & 0.00 & $534,594.52$ & $153,466.90$ \\
\hline 13.05.2017 & $\mathrm{L}$ & 0.00 & $254,150.46$ & 0.00 & $534,689.04$ & $280,538.58$ \\
\hline 12.11 .2017 & $\mathrm{~L}$ & $75,543.84$ & $266,403.31$ & 0.00 & $551,986.30$ & $285,582.99$ \\
\hline 13.05 .2018 & $\mathrm{Q}$ & $73,251.71$ & $273,154.21$ & $194,094.52$ & $375,070.89$ & $101,916.68$ \\
\hline 13.11 .2018 & $\mathrm{~N}$ & $71,195.89$ & $243,783.21$ & $138,043.84$ & $250,047.26$ & $6,246.05$ \\
\hline 13.05.2019 & $\mathrm{N}$ & $68,915.58$ & $184,332.38$ & $71,054.11$ & $187,535.45$ & $3,203.06$ \\
\hline 13.11 .2019 & $\mathrm{~N}$ & $66,847.95$ & $61,713.19$ & $131,521.92$ & $62,511.82$ & 798.63 \\
\hline 12.05 .2020 & $\mathrm{~N}$ & $64,638.53$ & 0.00 & $64,538.53$ & 0.00 & 0.00 \\
\hline
\end{tabular}

* Indications concerning the classification of the loan: $\mathrm{N}$ - normal, $\mathrm{Q}$ - questionable, $\mathrm{L}$ - lost.

Source: own elaboration. 
On 13.05.2018, the borrower has paid all the overdue credit, presenting a net loss, which still breached the share capital. From 13.11.2018, the repayment of the loan and interest ran smoothly, and the debtor rebuilt their equity and became a viable entity.

If the borrower had kept his contractual maturity of the loan and interest, ESP would have been at $11.14 \%$, however, due to a delayed service, the effective rate was $9.85 \%$. The carrying value of the loan, determined at amortized cost, is lower than the amount corresponding to the required payment, which is presented in col. 7 , Table 2. This is extremely important because the analysis of the carrying value of exposure leads to the conclusion that the commitment of the bank to the borrower is lower, and that means that incurred credit risk is lower in relation to receivables valued at the due amount.

\section{The security of the credit exposure and its value}

A mortgage is one of the limited property rights, whose full catalogue is listed in the Civil Code [Ustawa z 23 kwietnia 1964]. Limited property rights, also known as rights to someone else's belongings, ensure that an authorized person (laying down the law at the request of the owner) has clearly defined terms of reference in relation to belongings. This means that the authorized person's power is limited to those powers that are conferred by the legislature, but their range is narrower than relating to property rights [Hołyst (ed.) 2005].

The function of a mortgage is to secure monetary claims by charging the real estate or its fractional part which belongs to the co-owner, with such a result (mortgage goal) the creditor may claim satisfaction of claims of the encumbered real estate regardless of who its current owner is, and claim priority over personal creditors of the owner [Bieniek, Rudnicki 2006]. The object of the mortgage can be, outside of real estate, perpetual usufruct with buildings and equipment on the area, as well as the cooperative ownership right to the property.

To secure the loan, a mortgage is usually established on the property owned or co-owned by the borrower. The definition of the property is defined in the Civil Code (Art. $46 \S 1$ ) and states that the properties are part of the earth's surface which constitute separate property (land), as well as buildings permanently attached to the land or parts of such buildings, if, under the specific provisions, they constitute an ownership status distinct of land. This means that the material form of the property consists of two components: the "mandatory" (part of the natural constant), which is the ground and the "optional", which may include natural variable factors (e.g. plants) or resulting from human activities (e.g. buildings and equipment permanently attached to the land).

The Polish civil law is based on the Roman principle superficies solo cedit, which states that what is on the surface belongs to the land underneath it. From a legal point of view, only the components of the property cannot be the subject 
of ownership and other property rights, while from the "technical" point of view, the components consist of everything that cannot be removed without damage or material change to the disconnected object, whereby as components of the property there are also considered the rights associated with its ownership. The components, therefore, add specific legal, physical and utilitarian qualities to the real estate, and at the same time make it necessary to perceive them also from an economic point of view, especially due to their monetary value. This means that as a result of a mortgage on the property, the ground and its constituent elements are also charged with the mortgage [Wiszniowski 2014].

Since the subject of securing banking debts may be real estate, and the mortgage is the law under which the bank can enforce its claims, from the point of view of the creditor the most important should be the outcome of the evaluation indicating whether an entry made on mortgage which charges the property is adequate to the value of the property. It is not economically justified that the amount of the fees should exceed the value of the collateral. The same principle should apply when the mortgage is established in favour of several creditors. In that case, the sum of the entries should not exceed the value of the property, whereas the term "real estate values" in the S Recommendation should be clarified.

This is due to the fact that on key issues, such as, for instance, the definition of $L t V$, the FSC's recommendation uses the general term "value of the property." Even though the recommendation cites the term "market value," it is in the context of the duty of monitoring the value of the collateral. Indeed, knowledge of the market value of the property is valid at the time when the loan is granted and in its duration when assessing the adequacy of the collateral, but its direct use in measuring risks derived from credit exposure secured by mortgage is not justified. It is important to remember that market value for a specific collateral is a hypothetical value, because it is the most likely price realisable on the market, determined according to the transaction prices with the assumptions of independence of the parties to the transaction of sale, the lack of this sale in the conditions of a forced situation, and a firm decision about its conclusion as well as the establishment of the necessary time to expose the real estate on the market and to negotiate the terms of the contract [Ustawa $\mathrm{z} 21$ sierpnia 1997]. Incorrect or improper assumptions for the valuation of the property by the appraiser performing the valuation of the property who is not a professional in the field of banking, does not burden this person, but the financing bank which bears the credit risk.

In these circumstances, it appears that, for the needs of this publication, the term "banking value of the property"should be used, where the rules for determining should refer to the term "assessment of the value of real estate collateral" used in the $\mathrm{S}$ Recommendation. This term refers to an estimate by the bank of a realisable amount of money from the real estate collateral of the credit exposure, applicable at the time when the loan is granted, or at the time of making the next valuation, conducted on the basis of statistical methods or on the basis of the analysis of the real estate 
market [Uchwała nr 148/2013]. In other words, it is suggested that banks should always verify the value of the property presented in the appraisal reports prepared by authorised persons, in the context of their own research involving, among others, market analysis, the duration and effects of the economic recovery of the real estate (the so-called "recovery rate"), including the costs of these processes, as well as the amount of mortgage entries made for other services or by other creditors.

Another issue that is not addressed in the S Recommendation is the problem of industrial real estate, where the degree of equipment in technical infrastructure and machinery is often very complicated in the technical and legal sense, and the state is the result of mutual sustainable links between land, buildings and equipment [Wiszniowski 2014]. This matter should be the subject of interest to the Financial Supervision Commission, which as a public supervisory authority over banks should adopt cooperation with the Ministry of Justice and the legislator in this regard.

\section{Dilemmas in measuring risk exposures secured by mortgages}

In support of the need to apply the provisions of the $\mathrm{S}$ Recommendation, the Financial Supervision Commission drew attention to the fact that one of the objectives of regulation is to ensure the quality of loan portfolios built by the banks, which lies not only in their interest, but also the economy of the country and all participants in the real estate market. Without questioning that noble goal that prompted the FSC to develop their recommendations, it should be noted that one of the basic conditions for the success of this plan is the credibility of the information managed by banks to a wide range of stakeholders.

FSC also believes that the condition for the success of the development of the real estate market in the broad sense of the term includes the standardisation of high quality loan portfolios, and one of the indicators determining this success is to keep $L t V$ at the recommended level. This parameter is defined as an "indicator which expresses the value of the credit exposure to the real estate value," and its recommended limit values are established separately for residential and commercial properties. Generally, in the case of residential property, the maximum $L t V$ ratio should be $80 \%$, while in the case of credit exposures secured on commercial property this value should not exceed $75 \%$.

It is prudent to ask at this point, does the S Recommendation not cause doubts in calculating the $L t V$ ?

The literal meaning of the $L t V$ abbreviation is loan to value and therefore the relationship between the debt of the borrower, known by the day on the measurement, and the recoverable amount of the collateral in the form of a mortgage on the property. The debt is to be understood as determined by the bank: the total amount of the outstanding loan capital and accrued contractual interest, including eventual penalty interest and other charges or claims by the bank (e.g. the costs of the enforcement proceedings), while the value of the collateral should correspond to the amount of 
money that can be recovered by the bank from the mortgage collateral. Therefore, if the bank will assess the monetary value of the collateral in such a way that the starting point for determining the security will be the market value of the property determined by the appraiser (or bank), checked and possibly adjusted for the results of their research on the degree of "recoverability" and then confronted with the entry, thusly set value of the collateral should be the basis for calculating the $L t V$.

\section{Example 2}

The bank approved a loan in the amount of 1,000,000 PLN to finance the purchase of a new technological line. The commission was $5 \%$ of the loan amount and was deducted at the time of its launch. Collateral for the loan was a mortgage in the amount of 1.276 million PLN established on a property with a market value equal to 2,700,000 PLN. The current copy of the land register showed that, before granting the loan, other creditors established a mortgage totalling to 1,100,000 PLN. The "recoverability" was $88 \%$ and should be understood as the ratio of the amount obtained during the recovery to the market value of the property.

Table 3. Comparison of the $L t V$ values

\begin{tabular}{|c|c|c|c|}
\hline \multirow[b]{2}{*}{ No. } & \multirow[b]{2}{*}{ Specification } & \multicolumn{2}{|c|}{$\begin{array}{l}\text { Values on the date of the approval } \\
\text { of the loan }\end{array}$} \\
\hline & & $\begin{array}{l}\text { according to the } \\
\text { wording if the } \mathrm{S} \\
\text { Recommendation }\end{array}$ & $\begin{array}{l}\text { according to } \\
\text { the author's } \\
\text { proposition }\end{array}$ \\
\hline A & $\mathrm{B}$ & $\mathrm{C}$ & $\mathrm{D}$ \\
\hline 1 & $\begin{array}{l}L t V \text { counter: } \\
\text { Col. C - carrying amount of credit exposure } \\
\text { Col. D - the value of the amount requiring } \\
\text { payment }\end{array}$ & 950,000 PLN & $1,000,000$ PLN \\
\hline 2 & \multicolumn{3}{|l|}{$\begin{array}{l}L t V \text { denominator: } \\
\text { Col. C - "property value" } \\
\text { Col. D - the collateral value after adjustments }\end{array}$} \\
\hline 2.1 & $\begin{array}{l}\text { The market value of the property determined by } \\
\text { the appraiser or a bank }\end{array}$ & \multicolumn{2}{|c|}{$2,700,000$ PLN } \\
\hline 2.2 & $\begin{array}{l}\text { The "recoverability" indicator determined based } \\
\text { on the results of analyses carried out by the bank }\end{array}$ & \multicolumn{2}{|l|}{$88 \%$} \\
\hline 2.3 & $\begin{array}{l}\text { The value of the property after correction accor- } \\
\text { ding to paragraph } 2.2 \text { pos. } 2.1 * \text { pos. } 2.2\end{array}$ & \multicolumn{2}{|c|}{$2,376,000$ PLN } \\
\hline 2.4 & $\begin{array}{l}\text { Entries on mortgages made by other creditors } \\
\text { before granting credit }\end{array}$ & $\begin{array}{l}\text { Not included, because } \\
\text { the value of the property } \\
\text { does not depend on the } \\
\text { quantity or value } \\
\text { of mortgage entries }\end{array}$ & $1,100,000$ PLN \\
\hline 2.5 & The collateral value after the correction & $2,376,000$ PLN & $1,276,000$ PLN \\
\hline 3 & $L t V($ pos. $1 /$ pos. 2.5$)$ & $40.0 \%$ & $78.4 \%$ \\
\hline
\end{tabular}

Source: own elaboration. 
In the example, there was carried out a comparative study between the $L t V$ value by the literal wording of its definition contained in the S Recommendation in relation to the method of determining items affecting this indicator proposed in this paper.

The results of the calculations concerning the $L t V$ made based on the definition given in the S Recommendation lead to the presentation of a lower value of this indicator than in the case of determining the real value of collateral made on the property. This discrepancy in the analysed case is almost double the amount, and results from the fact that the $\mathrm{S}$ recommendation requires the calculation of the $\mathrm{LtV}$ by the carrying amount EKZH in relation to the value of the property. According to the proposal by the author of this publication, it should be the value of the debt of the borrower at the amount payable in relation to the value of the collateral, which takes into account not only an adjustment for "recoverability" but primarily the entry on mortgages for the bank, while taking into account previously made entries (chronological order for the satisfaction of mortgage creditors).

In the framework of the analysis and the assessment of risks, banks are required to disclose information about the incurred credit risk, including the related credit exposures secured by mortgages. The $\mathrm{S}$ Recommendation does not address this issue in relation to the loan portfolio, which in practice means that banks can quite freely shape the method of calculating this indicator, showing lower $L t V$ values of the portfolio than it is in reality.

\section{Example 3}

Before drawing up the annual report, presenting, among others, the level of risk derived from mortgage-secured loans, the bank is considering the calculation of the $L t V$ for credit portfolio in two variants: the relationship of total debt of the borrowers to the total value of the collateral, and according to the weighted average, where the weight is the debt of individual borrowers. Due to the unfavourable other measures of assessing the bank's operations, the institution strives to present the best possible $L t V$ indicator for itself.

The calculations show that the favourable $L t V$ ratio is the one which was calculated as the ratio of the total debt of the borrowers to the total value of all collaterals $(62.8 \%)$. However, this is not a value corresponding to the actual one, because the mortgages secure specific loans, and thus the adoption of global values does not reflect the actual credit risk incurred by the bank. For example, in position 1 in Table 4, the debt of the borrower is only 200,000 PLN, and the value of collateral is $2,600,000 \mathrm{PLN}$. The $L t V$ ratio for this exposure is $7.7 \%$, but this does not mean that such a low value of this parameter affects the other exposure. The calculation of the weighted average provides a completely different result, because the $L t V$ is at $72.4 \%$. The difference between the two variants should be considered significant, since it amounts to 9.6 p.p. (or 15.3\%). It leads to the inclination that the FSC should clarify the rules for calculating the $L t V$ for loans. 
Table 4. The method of calculating the $L t V$ value

\begin{tabular}{|c|r|r|r|r|r|}
\hline $\begin{array}{c}\text { The number } \\
\text { of the } \\
\text { borrower }\end{array}$ & $\begin{array}{c}\text { The debt of the } \\
\text { borrower at } \\
\text { the date of the } \\
\text { analysis }\end{array}$ & $\begin{array}{c}\text { The value of the } \\
\text { collateral }\end{array}$ & $\begin{array}{c}\text { LtV of } \\
\text { individual } \\
\text { borrowers, } \\
\%\end{array}$ & $\begin{array}{c}\text { The debt } \\
\text { structure, \% }\end{array}$ & $\begin{array}{c}\text { LtV of the } \\
\text { bank's loan } \\
\text { portfolio, \% }\end{array}$ \\
\hline A & B & C & D & E & F $=$ D $\times$ E \\
\hline 1 & 200,000 PLN & $2,600,000$ PLN & 7.7 & 1.9 & 0.1 \\
\hline 2 & 600,000 PLN & 750,000 PLN & 80.0 & 5.8 & 4.7 \\
\hline 3 & $1,400,000$ PLN & $2,000,000$ PLN & 70.0 & 13.6 & 9.5 \\
\hline 4 & 750,000 PLN & $1,100,000$ PLN & 68.2 & 7.3 & 5.0 \\
\hline 5 & 200,000 PLN & 250,000 PLN & 80.0 & 1.9 & 1.6 \\
\hline 6 & 400,000 PLN & 600,000 PLN & 66.7 & 3.9 & 2.6 \\
\hline 7 & $3,300,000$ PLN & $4,200,000$ PLN & 78.6 & 32.0 & 25.2 \\
\hline 8 & $1,250,000$ PLN & $1,600,000$ PLN & 78.1 & 32.0 & 9.5 \\
\hline 9 & $1,200,000$ PLN & $1,900,000$ PLN & 63.2 & 11.7 & 7.4 \\
\hline 10 & $1,000,000$ PLN & $1,400,000$ PLN & 71.4 & 9.7 & 6.9 \\
\hline Total & $10,300,000$ PLN & $16,400,000$ PLN & 62.8 & 100.0 & 72.4 \\
\hline
\end{tabular}

Source: own elaboration.

\section{Conclusions}

The purpose of measuring the credit risk is the assessment of the degree of the risk of the bank's losses, which stem from outstanding credit receivables. In the case of credit exposures secured by mortgages, risk analysis should pertain to thus defined variables influencing $L t V$, so that the way of their determination will not raise any doubts in banks. The S Recommendation in the current wording does not satisfy this condition.

The considerations undertaken in this publication allow to present proposals for calculating the $L t V$ according to the following formula:

$$
L t V=\frac{\mathrm{EKZH}}{\mathrm{BWN}},
$$

where: EKZH - the exposure value of credit secured by mortgage on the day of the measurement of the $L t V$ indicator. This value should match the bank's receivables in the amount due, including the unpaid loan capital, contractual interest, as well as overdue and other claims of the bank arising from the exposure; BWN - bank value of the property received by the bank on the basis of an assessment of its value, relative to the amount of the entry of the mortgage, taking into account the adjusted market value of the property, the "recoverability", and prior mortgages on the property. 
The formula to calculate the $L t V$ ratio of the loan portfolio of the bank, whose mathematical form is portrayed below, requires defining:

$$
L t V_{\text {porffela }}=\sum_{i=1}^{n}\left(U_{i} \times L t V_{i}\right)
$$

where: $L t V_{\text {portfela }}-L t V$ ratio of the bank's loan portfolio; $U_{i}-$ the percentage of the value of individual EKZH in the loan portfolio at the amount due; $L t V_{i}-L t V$ value of individual EKZH; $i$ - the number of individual EKZH.

Carried out considerations proved the truth of hypothesised of exploratory. The economic image of the bank bearing the credit risk coming from EKZH is subordinated from the construction of measures describing the dependence between the indebtedness and a collateral value of hypothecary and the way of defining variable of having influence on their value.

Proposed of the modification of the way of the calculation of $L t V$ for the individual credit exposure secured by a mortgage and the introduction in the Recommendation $\mathrm{S}$ of the model of the calculation of LtV for the credit-portfolio, should significantly limit or eliminate possibilities of the creative formation of the image through banks of within the range taken a risk of the essential part of the credit-portfolio. The fulfilment of this postulate will not cause the appearance of additional costs after the side of banks and does not tie in with gaining of the additional information, because all elements formative $L t V$ are recorded in systems of information banks or loan departments, in this "ratio recoverability."

\section{References}

Apanowicz J., 2010, Metodologiczne elementy procesu poznania naukowego w teorii i organizacji zarządzania, Wyższa Szkoła Administracji i Biznesu, Gdynia.

Bieniek G., Rudnicki S., 2006, Nieruchomości. Problematyka prawna, LexisNexis, Warszawa.

Hołyst B. (ed.), 2005, Wielka encyklopedia prawa, Wydawnictwo Prawo i Praktyka Gospodarcza, Warszawa.

KNF, 2016, Wystapienie KNF do Związku Banków Polskich z 10.10.2016 r., www.knf.gov.pl (access 15.10.2016).

Kostecki S., 2014, Wierzytelność a rzeczowe zabezpieczenia na nieruchomości, Lex, Warszawa.

Roubini N., Mihm S., 2011, Ekonomia kryzysu, Oficyna a Wolters Kluwer, Warszawa.

Wiszniowski E., 2014, Ekonomiczne granice nieruchomości przemysłowej a wartość wskaźnika LtV, Problemy Zarządzania, Uniwersytet Warszawski, Warszawa.

\section{Legal acts}

Rozporządzenie Komisji (WE) nr 1126/2008 z dnia 3 listopada 2008 r. przyjmujące określone międzynarodowe standardy rachunkowości zgodnie z rozporządzeniem (WE) nr 1606/2002 Parlamentu Europejskiego i Rady, Dz. Urz. UEL I.320 ze zm. 
Rozporządzenie Ministra Finansów z dnia 16 grudnia 2008 r. w sprawie zasad tworzenia rezerw na ryzyko związane z działalnością banków, tekst jedn. Dz.U. 2015.2066.

Rozporządzenie Ministra Finansów z dnia 1 października 2010 r. w sprawie szczególnych zasad rachunkowości banków, tekst jedn. Dz. U. 2013.329.

Rozporządzenie Parlamentu Europejskiego i Rady (UE) nr 575/2013 z 26 czerwca 2013 r. w sprawie wymogów ostrożnościowych dla instytucji kredytowych i firm inwestycyjnych zmieniające rozporządzenie (UE) nr 648/2012, Dz. Urz. UE 27.6.2013 ze zm.

Uchwała nr 148/2013 Komisji Nadzoru Finansowego z dnia 18 czerwca 2013 r. w sprawie wydania Rekomendacji S dotyczącej dobrych praktyk w zakresie zarządzania ekspozycjami kredytowymi zabezpieczonymi hipotecznie, Dz. Urz. KNF 2013.23.

Ustawa z 23 kwietnia 1964 r. Kodeks cywilny, Dz.U. nr 16 poz. 94 ze zm.

Ustawa z 21 sierpnia 1997 r. o gospodarce nieruchomościami, tekst jedn. Dz.U. 2015.1774 ze zm.

Ustawa z 2 lipca 2004 r. o swobodzie działalności gospodarczej, tekst jedn. Dz.U. 2015.584 ze zm.

Ustawa z 29 września 1994 r. o rachunkowości, tekst jedn. Dz.U. 2013.330 ze zm.

\section{NIEDOSKONALOŚCI NADZORCZYCH REGULACJI OSTROŻNOŚCIOWYCH W ZAKRESIE EKSPOZYCJI KREDYTOWYCH ZABEZPIECZONYCH HIPOTECZNIE}

Streszczenie: Wiarygodność informacji ekonomicznej przekazywanej przez banki jest jednym z kluczowych elementów budowy zaufania między tymi instytucjami a otoczeniem gospodarczym. Działalność krajowego sektora bankowego, z racji szczególnej odpowiedzialności za powierzone depozyty, podlega restrykcyjnym unormowaniom prawnym i jest kontrolowana przez nadzór bankowy. Obowiązującym banki aktem prawnym regulującym między innymi zasady pomiaru ryzyka kredytowego pochodzącego od ekspozycji kredytowych zabezpieczonych hipotecznie jest Rekomendacja S, która została wydana przez Komisję Nadzoru Finansowego. W publikacji omówiono niedoskonałości tej regulacji nadzorczej w zakresie definiowanych pojęć oraz zalecanych metod pomiaru wartości ekspozycji kredytowej, interpretacji i sposobu ustalania wartości zabezpieczenia hipotecznego oraz wskaźnika $\mathrm{Lt} \mathrm{V}$, będącego podstawowym miernikiem pomiaru ryzyka kredytowego ekspozycji zabezpieczonych hipotecznie.

Słowa kluczowe: $L t V$, zabezpieczenie hipoteczne, nieruchomości, ryzyko kredytowe, Rekomendacja S. 